\title{
The emergence and impact of neoliberal ideology on UK public library policy, 1997-2010.
}

Margaret Greene, Masters Graduate, Department of Computer and Information

Sciences University of Strathclyde

David McMenemy, Lecturer, Department of Computer and Information Sciences, University of Strathclyde

\begin{abstract}
Over the last thirty years, the globalisation of neoliberal ideology has been pervasive and all encompassing. The chapter uses a mixed methods approach by combining content and discourse analysis to examine how neoliberal discourses have impacted on public librarianship. Since New Labour's election in 1997 public service restructuring in the United Kingdom has taken on a more oblique managerialist and consumerist approach. The impact of managerialism in the public library service has focused mainly on modernising and improving services to the individual user, and is based on scenarios where public libraries have to model themselves on the private sector, and where managers have been empowered over professionals. The wider shift away from collectivist service provision to more personalised and individualised forms of consumption are also explored, which is epitomised by the rise of the citizen consumer. The growing concern with the transformation of professional library language and the adoption of neoliberal doctrine is examined. Moreover, the rhetorical use of language and strategies to justify change and transformation are examined and also how at times there has been an "unquestioning" acceptance of neoliberalism by some public librarians (McMenemy, 2009b; Buschman, 2005).
\end{abstract}

\section{Introduction}

The victory of neoclassical economics over the earlier more adopted Keynesian approach was complete in the 1980s with the election in the United Kingdom (UK) of Margaret Thatcher in 1979. Emphasising less state intervention in the markets and less place for the state in providing services to consumers, the belief that the market must be left to operate with minimum intervention from the state became the overarching political thesis of all mainstream political parties in the UK.

The concept of the primacy of the market was not only apparent in the private sector; under neoliberalism it has been used as a way to critique the public sector as a privileged sector that lacked efficiency, and largely consisted of professions working against the interests of the people they purport to serve (Clarke \& Newman, 1997). From New Labour's election in 1997 public service restructuring in the United Kingdom continued the neoliberal approach, with the linked considerations of managerialism and consumerism impacting on the delivery of public services. In the context of library and information services the neoliberal approach has involved, amongst other things, mimicking the language of the private sector by redefining the library user as a "customer" (Budd, 1997). In addition the rhetorical use of language and strategies to justify change and transformation as a positive necessity is seen by 
some to be at the root of the ready and at times "unquestioning" acceptance of neoliberalism in public library services (Buschman, 2005; McMenemy, 2009b).

The associated wider shift away from collectivist service provision to more personalised and individualised forms of consumption epitomised by the rise of the "citizen consumer" has been accused of diluting the influence of traditional professional values (Clarke, 2007a, 2007b; Clarke \& Newman, 2007; Clarke, Newman, Smith, Vidler, \& Westmarland, 2007).

The introduction of the concept of choice for individual public service users is an example of a neoliberal rhetorical tool used to overcome any foreseen resistance to marketisation and restructuring of the public sphere (Clarke, et al., 2007). Moreover, the "common sense" nature of neoliberal discourses which plays on the emotions and logic of the individual has been challenged as an appropriate language for professionals (Budd, 1997; McMenemy, 2009b). The former in particular warns of the mindless adoption of language which he feels is at odds with the library mission and core values of public librarianship.

Most of the literature examining the impact of neoliberal discourses on public sector services, however, has emanated from those involved in social policy areas such as health and social care (Clarke, et al., 2007) and education (Basu, 2004), and only recently public librarianship (McMenemy, 2007, 2009a; Usherwood, 1996, 2007). This chapter aims to examine what has been referred to as a "relatively underanalysed area" in public library research: the impact of neoliberal theories on public librarianship (McMenemy, 2009b).

Yet clearly public librarianship has a potential dilemma; it cannot exist outside of the prevailing political and economic climate, therefore it could be argued there is some necessity in the profession developing the language of the politicians who administer the sector. However what challenges does this necessity pose to the profession and the service, and how is the message being articulated?

\section{Literature review}

Over the last thirty years, there has been a rapid globalisation of the capitalist economy and the neoliberal principles of individualism, privatisation, and decentralisation have become increasingly evident in public sector services (Basu, 2004). Moreover the tenets of marketization have progressively infiltrated professional discourses serving the public such as education, health, social care, policing and librarianship (McMenemy, 2009b). This review of the literature will highlight some areas where this has occurred.

\section{Commodification of public librarianship}

The application of marketing principles and techniques to public librarianship has been a debatable topic for the last thirty years since marketing was extended to nonprofit organisations (Kotler \& Levy, 1969). There is an abundance of articles on marketing and library and information services looking at various topics including the influence of personality regarding the attitudes of public librarians towards marketing, and how personality has influenced the likelihood of the libraries at adopting 
marketing practices (Aharony, 2009), an investigation of the connection between the marketing attitudes and behaviour of librarians, and finally how corporate culture has impacted on libraries around the world (Panda \& Mandal, 2006).

This is again evident in the rise of commercialisation in the public library space through the endorsement of market practices such the development of the bidding culture in public libraries (Hood \& Henderson, 2005; McMenemy, 2009b; Parker, Ray, \& Harrop, 2001), pushing direct marketing to the public library user (McMenemy, 2008), the diversification of public libraries into income generation and the adoption of the coffee shop model under the pretext of "service modernisation" (Budd, 1997; Buschman, 2005; McMenemy, 2009b; Rooney-Browne \& McMenemy, 2010).

\section{Managerialism and public libraries}

Managerialism, or New Public Management (NPM), is the term used to describe the move towards a managerial style of public sector service provision, dubbed managerialism, and has been widely practiced in public services since the late 1980s. It is asserted that as managerialism and professionalism work from opposing ethos that the introduction of the former into public services has led to the "dumbing down" of public libraries in the UK (Usherwood, 2007).

Managerialism is a more applied approach to management of the public sector and is characterised by an ideological obsession with the benefits of quantitative measurement to determine service quality (McMenemy, 2007, p.446). However, some have voiced their concern with what they feel is the unquestioning way many librarians have "blindly accepted" the targets driven philosophy without evidence to prove it is "fit for purpose" (McMenemy, 2007; Usherwood, 1996, 2007), which they suggest is ultimately detrimental to services and the role of the professional.

\section{Deprofessionalism}

Increasing commercialisation in public library authorities has lessened the influence of traditional professional values (Broady-Preston \& Cox, 2000), to the point that they are regarded as something of an "anachronistic hindrance" (p.153). There has been a turn against professionalism and an apparent backlash against professionals and the assumption that their expertise would provide the correct solution for people (Needham, 2007); this is indicative of the wider social and political shift away from collectivist service provision to more personalised and individualised patterns of consumption brought in by the rise of the citizen-consumer (p.50). The need to reform public service provision is legitimised in neoliberal terms as the need to "keep up" and introduce new modes of production to maintain efficiency and service quality and has manifest itself in the increasing emphasis amongst public librarians on commercial as opposed to professional values. Usherwood (2007) found in his comprehensive study that less than half of those surveyed thought that public libraries should counteract the negative effects of commercialism in the public library sector.

Usherwood (2007) complains about the apparent apathy of public librarians to bring about change in the profession. They are accused of reacting to rather than leading 
government policy and allowing, without question, the growing commercialization of the public library service. Rather, he argues that the public library service should "provide an alternative to the many commercial institutions to be found in our society" (p.49). Moreover, he warns that the public library service should not follow the commercial model of service provision if it wishes to maintain equality of access as it will worsen social exclusion because, he argues, it favours the rich over the poor (p.51).

\section{Citizen-Consumers}

The reform of the public services in the UK has focused largely on a notion of citizens as consumers of public services, and is associated with wider social transition to a consumerist society and culture (Clarke \& Newman, 2007). The hybrid term "citizen-consumer" is an example of an ideologizing collocation (Chun, 2009) first employed by New Labour in a Green paper on welfare reform in 1998 (Clarke, et al., 2007). The debate surrounding the citizen-consumer is constructed around the binary distinction between state and the market and other related binaries: public/private; collective/individual; de-commodification/commodification (Clarke \& Newman, 2007). Choice has also become the key term indicating a move towards a consumerist stance in public services. Clarke et. al., (2007) state that the "choice" discourses that pervade New Labour policies on public service reform is derived directly from the market model of choice, which denotes choice being exercised by a "sovereign" consumer in pursuit of individual needs and aspirations.

Budd argues that neoliberalism operates most effectively through rhetoric (Budd, 2008) and consequently that the choice offered under this regime is illusionary and limited (p.174-75). The rhetoric of neoliberalism relies on naturalising the language of markets and transactions into everyday usage and which eventually means they can be represented as the truth.

Needham (2007) identifies three key narratives of consumerism that inform public service reform under New Labour in the UK. The first is standardisation, which Needham defines as a Fordist "one-size-fits-all" approach to service delivery which focuses on fairness and equity of access to information and public services which are fairly consistent, predictable and uniform in nature. The second narrative identified by Needham (2007) is differentiation which denotes the shift towards more tailored services to meet the individual needs of the user: the citizen-consumer is the recipient of personalised and differentiated services (p.37). Moreover, Needham discussed the "layering" of the first narrative which when established allows the next layer of choice and differentiation to take place. There are instances, Needham argues, whereby the emphasis of equity is in conflict with the emphasis on choice in the second narrative. There is also evidence of non-consumerist narratives of coproduction in the public service discourses which emphasise is on the role the consumer plays in the service outcomes (p.41). The chapter will later explore the evidence of these narratives in the public library literature.

\section{Modernity and the Use of Language}

Clarke has examined how New Labour has used the language of binary opposition to suggest social change, progress and modernisation (Clarke, 2007a, 2007b). For 
example, New Labour tries to distance itself from an old regime (Keynesian) of collective public services and aligns itself with the new regime (neoliberalism) with its emphasis on the individual and citizen consumer. The former society is portrayed as homogenous and less dynamic and in need of change, while the new society is based on consumer choice, responsiveness and flexibility (Clarke, 2007b).

The core themes associated with these "transformist discourses" proposed by neoliberalists involve citizen-consumerism, diversity, choice, empowerment, the rise of the expert-user (Clarke, 2007a) and are also linked to wider ideologies surrounding what Giddens calls the "third way politics" of New Labour and the critical framework based on "new public philosophy" (Buschman, 2003). Furthermore, Buschman argues that public libraries are the embodiment of Habermas's classical definition of the public sphere (Buschman, 2005), which is the "sphere of non-governmental opinion-making" in which the economic side of development (at present neoliberalism) dominates (p.3).

\section{The impact of neoliberal discourses on professional language}

The language in many public service providers has been influenced by neoliberal tenets of marketisation and commercialisation. Harvey succinctly argues (Harvey, 2005) that the "conceptual framework" of neoliberalism appeals to general electorates' intuition and common sense (p.5) and consequently the acceptance of the policies are taken for granted and so are less likely to be challenged. Basu, for example, looks at globalisation of neoliberal solutions to education problems in Ontario, Canada and the success of ideological discourse due to the ideal message it conveys (Basu, 2004). Moreover, he highlights a period of economic and political reform in the 1990s in Ontario's education system that involved the implementation and acceptance of neoliberal ideology during what was referred to as the "Common Sense Revolution" instigated by the Progressive Conservatives (Basu, 2004).

Basu's (2007) research highlights the strategies and techniques used to implement neoliberal ideology including rationalisation, political rhetoric and quangos. This provides a helpful platform on which to look at "transformative discourses" (Buschman, 2005) surrounding public librarianship. The use of language by political parties is a potent persuasive tool that can persuade the public and professionals that the new policies of commercialism are being introduced for the benefit of the service and not for any political reason (McMenemy, 2009c). Rationalisation is also a strategy used by governments to persuade the public of the importance of remaining globally competitive in a knowledge-based economy allowing them to introduce potentially unpopular policies in the public sphere. This can be seen in public libraries when policies such as those introducing an "audit culture" and league tables were introduced under the pretext of efficiency and value for money (Basu, 2007).

\section{Dissolution of the Public Realm: Democracy and Public Librarianship}

Public libraries and librarians have been described (Buschman, 2003) as essential ingredients to a healthy and functioning democracy. Public libraries and the professional ethics of the professional librarians are necessary for the access and preservation of information for an informed citizenry, and denote an important link in "the chain of knowledge" (p.7). While public libraries continue to play an important 
part in creating democratic access to information and resources (Rooney-Browne, 2008), their social, educational and leisure role is being increasingly supplanted by other commercial alternatives (Rooney-Browne, 2008; Rooney-Browne \& McMenemy, 2010).

\section{Experiences outside of the United Kingdom}

The literature also suggests that the UK has not been alone in experiencing this change in approach to how public libraries are perceived. Denmark has seen the encouragement from central government for public libraries to earn fees and become self-sustaining (Johannsen, 2004a, 2004b), a result of "budget cuts and New Public Management" (Johannsen, 2004b, p.22). However a study of the attitudes of librarians towards these changes highlighted no evident change in ethos in public libraries, with senior staff largely managing to downplay the external demands of the politicians.

Another Danish study discusses the changes in management approach that need to occur if political legitimacy is to be achieved for public libraries in the modern era, with an emphasis on embracing the concepts of change, competition and the need to be appropriately evaluated (Kann-Christensen \& Pors, 2004).

Evidence of concentration on neoliberal forms of public library evaluation are also evident in other countries' literature (Audunson, 2005)

\section{Benefits of the new approach}

While this chapter will focus on the challenges of the new regime, it would be churlish not to comment on the benefits of the new opportunities presented by neoliberalism. A more efficient management approach that is understood by politicians involved in local government strategy can clearly mean that the public library can be made to appear more responsive to the political needs of governing parties. In addition, the introduction of commercial services such as coffee shops offer a potential community locale that can be positive for members of that community to use, offering an enhanced social space, albeit a commercial one. The opportunities presented under neoliberalism for public libraries to be more modern, innovative, and responsive to community needs could be argued to be opportunities for public libraries to gain more relevance in the modern era, and indeed as we will see in the corpus have been argued to be so.

The literature review has highlighted many themes and discourses operating in the public service provision, but due to space constraints, the chapter will concentrate on three main neoliberal discourses particularly related to public librarianship: managerialism, consumerism and the dissolution of the public realm.

\section{Research methods and data analysis}

This remainder of the chapter presents specific research questions to be investigated via analysis of the corpus of documents produced by the UK government in the period 1997-2010 on the topic of public libraries. 
The research for this chapter was undertaken using a mixed methods approach. An extensive literature review identified themes within neoliberal discourses that were found to be impacting on public sector services in the UK; these themes were then considered in light of the literature in public libraries. A key concern was whether these themes were present within the policy documents of the UK government related to public libraries.

Specifically the questions that will be answered are:

1. How have the themes identified by Needham been articulated in public library policy documents, namely standardisation, differentiation, and production?

2. How has the concept of the citizen-consumer and choice been articulated?

The researchers analysed the content of the key policy documents in the period 1998-2010 using concordance software, and then examined the retrieved data for neoliberal discourse themes. Following Fairclough's (2000) example, the researchers explored the public library corpus of documents for keywords and phrases and looked for evidence of how wider social, political, economic and cultural discourses have influenced the social construction of meaning attached to particular words. Discourse analysis specifically explores the broader social reality and institutional structures in which the discourses are constructed (Budd \& Raber, 1996). As such, many feel that discourse analysis can play an important role in policy analysis (Rydin, 2005).

\section{The corpus of documents}

The researchers retrieved fifty-six public library documents, covering the period 1998 to 2010, from the Department of Culture, Media and Sports' (DCMS) website. These documents were chosen on the basis that they provided a ready access to what is determined to be, by the DCMS, the most pertinent public library documents available. After closer examination of the document content, however, four of the documents with poor thematic information such as the appendices of DCMS documents listing the names of steering group membership, Chartered Institute of Public Finance and Accountancy (CIPFA) statistics, and Public Library Service Standards (PLSS) statistics were removed. Thus, the reference corpus consisted of fifty-one documents (Appendix).

\section{Concordance Software: AntConc}

The researchers utilised AntConc ${ }^{1}$, a concordance software tool that offers great flexibility to process the high volume of data contained within the fifty-one public library documents. Following document selection, the researchers had to convert the documents (PDF format) to text files to make them usable by the software tool.

\footnotetext{
${ }^{1}$ A freeware, multi-platform, multi-purpose corpus analysis toolkit created by Laurence Anthony which includes a strong concordance, word and keyword frequency generator, tools for cluster and lexical bundle analysis and a word distribution plot. It also offers a choice of simple wildcard searches or powerful regular expression searches and has an easy-to-use, intuitive interface. (Anthony, 2005)
} 


\section{Exploring the corpus}

\section{Managerialism - deprofessionalism}

Over the last thirty years, the number of professionally qualified staff in public libraries has fallen significantly (Broady-Preston \& Cox, 2000), while those remaining find their role increasingly managerial in content, and title (p.153). A concordance search, using AntConc, returned 111 hits for the term "professional", and Tim Coates' report (Coates, 2004) Who's in Charge?: Responsibility for the Public Library Service report was one of the identified documents, which highlighted that in Coates' opinion the distinction between professionally qualified staff and library assistants is not required in order to provide "the best possible standard of service" to library users:

Most library services make a distinction between 'professionally qualified' staff and 'library assistants'. However the public assumes that all staff working in a library are librarians, and would hope to receive the best possible standard of service from whomever they address a request for help... The demarcation between professional and non-professional staff should cease. (p.20).

Thus, it can be inferred that either Coates feels that existing levels of expertise are not required to be a "librarian" and that a more uniform and basic level of training would suffice. There has been what some have described as an "anti-professional culture" pervading public services to the point that some (Usherwood, 1996) state that the word "professional" is almost a term of abuse (p.120). Some (KannChristensen \& Andersen, 2009) have suggested that this has its origins in the leftwing culture that did not want to patronise users and perpetuate an elitist view of culture and enlightenment (p.211). Indeed, there was some evidence in the public library documents of "anti-elitism" (DCMS, 2009b) such as a Councillor White who argues against "islands of specialism" in librarianship and suggests that public librarians:

Need to be consummate professionals with clear values, focussed on providing the information service citizens want to high standards. That professionalism may or may not be reflected in specific qualifications...The possessors of those skills should not have a privileged voice in informing policy... (p.62).

Kann-Christensen and Andersen (2009, p.209) feel that while it is inevitable and necessary for libraries to reconsider their function in society by evolving and adjusting to social change, the danger lies with their tendency to take over "a neoliberal way of thinking, which in the long run...may lead to their own death."

\section{Professionalism: Narratives of Decline}

The search for "professional" in AntConc also highlighted other narratives existing in the documents. Coates' document, for example, exhibited narratives of decline and inefficiencies. For example, Coates (2004, p.5) refers to the library service in terms of its "increasing cost and consequent deterioration in value for money" and talks about how "Library systems are extremely cumbersome" both of which implies an 
inefficient use of resources, (p.21). He also perpetuates the threat that "if we do not address the fundamental structural problems of the library service, there may be no libraries to provide these excellent services to" (p.1). The rhetorical use of the pronoun "we" is ambiguous as it is unclear whether he is using it inclusively to refer to the library profession and calling for them to "fix" the problems in the service or as he suggests in the next sentence to "Those who are responsible for libraries must change what they are doing" (p.1). This ambiguity is advantageous for him in the sense that he maintains an air of neutrality and so it may (arguably) make it easier for the reader to accept his predictions. However, at other times he shifts his allegiances toward the entitlements of the "taxpayer":

It is unfortunate that discussions about renovation of the library service become polarised so that those who campaign for and develop outreach, or information technology are somehow set against those who call for an improved range of books. Of course this is nonsense. All of these things must be provided, and if they are to be done, they must be done properly and in a thoroughly professional manner. That is what the public are entitled to demand for the funds which they pay. (Coates, 2004).

This narrative plays upon the public's anxiety and expectation about receiving good quality services which according to neoliberal discourses should display value for money and efficiency.

\section{Professional Paternalism: Social Value}

Ironically, some would argue (Kann-Christensen \& Andersen, 2009) that neoliberal pressure to think about libraries in economic terms has been at the expense of their social and cultural value (p.211). Moreover, libraries have focused on the user to validate their services and have been expected to use quantitative measures to assess and prove users' satisfaction with the service. Consequently, user needs and preferences are increasingly being used to measure service quality. There has also been a push by neoliberal politicians to move away from the traditional paternalistic relation with the user.

There is some evidence in the public library literature that there is a push towards making the public library service more commercially viable. One publication, for instance, considers the best type of commercial activities for libraries and suggests:

commercial activities or partnerships might be book selling or partnerships with bookshops, provision of coffee shops, rental of certain materials, contracts with local business, national partnerships with private companies (DCMS, 2009a).

Some question the appropriateness and impact of introducing such management techniques into evidence based practice like professional librarianship (McMenemy, 2007).

\section{Citizen-Consumer: Bookstore Model}


The need for public libraries to learn from the success and best practice of bookstores is part of a wider neoliberal discourse in UK politics that looks to the private sector for guidance on how to manage public sector service provision. Again, neoliberal market-driven consumerist discourses emphasise the "logical" connection between bookstores and libraries based on them both housing similar materials. The emergence of the "citizen-consumer" puts pressure on public services to perform and provide the same level of service that their users receive from the private sector (Clarke, et al., 2007). Budd, however, feels that by copying retail models of service provision that public libraries are abandoning their "contribution to a vibrant public sphere (Budd, 2008)"

neoliberalism has broken the connection there was between economic rights and civil liberties and that the language of markets, has been "naturalised" and has become part of everyday language to the point that individuals are unaware of using or even able to express themselves and be understood in alternative discourses. (p.212).

\section{Choice and Citizen-Consumers}

The collocation of citizen with consumer in public service reform in the UK is associated with the transition from a welfarist to a consumer society and consumer culture (Clarke \& Newman, 2007). It has been argued that (Clarke, 2004) choice is part of a wider neoliberal strategy to "depoliticise the public realm" and dissolve any form of public interest into a more individualised and consumerist desire for efficient and high quality services and to push social responsibilities from the public to the private sphere (p.32) Surprisingly, however, the term "citizen-consumer" is not used in any of the 51 publications examined for the chapter. The empowerment of the individual was developed in part through a new emphasis on choice (Needham, 2007, p.56).

It can be contextualised in the policies where public services are depicted as needing reform to keep globally competitive. They are portrayed as out of synchronisation with the transformations taking place in the "modern world". Hence, public services are then said to be in need of reform:

The population served by any library authority is not homogenous but comprises numerous large and small minority interest groups. In order to "provide a comprehensive and efficient library service for all persons desiring to make use thereof ", it is necessary to undertake a community profiling exercise; to identify the different market segments; and to adapt or develop existing services to better meet the needs of the different segments (DCMS, 2001a).

\section{Standardisation}

Needham (2007) identified "convenience" as a narrative of standardisation. Its use in the public library publications evolves over the years, but begins by discussing the term in relation to providing convenient and suitable access for the library users. The following quotation exhibits a focus on providing a uniform service to communities: 
Communications and information are the lifeblood of sustainable communities, and public services such as libraries, together with community groups, are often important conduits for information and knowledge. In disadvantaged communities isolation and inertia may constitute formidable barriers to the flow of information, personal relationships may be weak, and creative neighbourhood networks may function poorly...In such a context, the challenge is to help establish and sustain healthy conditions in which informal communication and the exchange of information can flourish. In these circumstances it is vitally important for communities to have a place to go to that is convenient, local and unintimidating (DCMS, 1999b).

The themes of differentiation in public service start to emerge in late 1999, when Tony Blair, the Prime Minister, starts to move away from a "'one-size-fits-all" approach of welfarist approach to public services. Individual user choice is integral to the notion of consumerism (Needham, 2007, p.102).

In Public Library Modernisation Review (DCMS, 2010), convenience is still relevant as a theme but with more emphasis on flexibility and meeting the user's 24/7 modern lifestyle. Consequently, it suggests that the public library should offer:

Flexible opening hours to suit the needs of the local people [and a] Commitment to customer service and expert, helpful staff...A safe local space which is accessible and convenient for the community...24 hour access: Through your library's online catalogue, online reference and other services....Services which reach out and attract local people including 'at home' services to housebound people (DCMS, 2010).

\section{Choice and Public Service Reform}

The second narrative identified by Needham (2007) is differentiation which denotes the shift towards more tailored services to meet the individual needs of the user: the citizen-consumer is the recipient of personalised and differentiated services (p.37). The themes of differentiation in public service also start to emerge in late 1999. The empowerment of the individual was developed in part through a new emphasis on choice (Needham, 2007, p.56). The concept of choice is inherent to a market culture, and indeed the concept has driven several works examining the potential impact of such a relatively simple concept on the lives of citizens. It has been argued by several authors that rather than being a liberating force, choice tyrannises the consumer through an over-abundance of possibilities and the inability of the consumer to always make an informed choice (Salecl, 2011; Schwartz, 2005).

In public library literature choice is deployed as a rhetorical tool to overcome public resistance to "markets" and as a means of introducing public sector reforms, and has a tendency to look to how things could be in the future compared to how they have been in the past.

\section{Choice: AntConc}

Consequently, the term "choice" was analysed using AntConc to evaluate the use of the word in public library documents over the period 1998-2010. As can be seen 
from Table 2, choice first appears in the publications in 2001 in relation to providing the users with a "choice in books and materials", but by 2003, in the Framework For the Future (Framework) publication (DCMS, 2003), the reader is invited to:

Imagine a place you can walk into, without anyone asking you a question, sit down at a computer, find and order almost any book ever published, which you can take home for free. This is not a shop but it offers people as much choice as a department store... (p.11).

Framework appears very aspirational in nature, and by comparing the level of choice offered in a library to that offered in a department store, it plays on the neoliberal notion of market superiority over states, preference of private over public provision and for individualism over collectivism. Moreover, there is other evidence in Table 1 of legitimising strategies being used to naturalise neoliberal discourse such as framing the term choice to talk about personalising user choice and encouraging the user to self-direct by giving the user, "....a choice of the way in which they can receive a reply" (DCMS, 2003). Moreover, hit 9 talks about a wide choice of suitable material, as well as an attractive environment which shows public libraries are introducing services that are tailored to the needs of their users and reveals a concern with service quality and efficiency (DCMS, 2005). Lastly, hit 6 reveals a concern for the equity of choice in relation to "housebound readers". Overall all of these discourses are framed in such a strategic and "common sense" way that it makes it more difficult for the individual to see reasons to challenge it in policy discourse.

Table 1. - Selected Key-Word-In-Context Records for Choice, 1998 -2010

\begin{tabular}{|l|l|l|}
\hline HIT & KWIC & PUBLICATION \\
\hline $\mathbf{1}$ & $\begin{array}{l}\text { [encourage the us]e the use made of the } \\
\text { library service; - provide choice in books } \\
\text { and materials made available to users; }\end{array}$ & $\begin{array}{l}2001 \text { - DCMS } \\
\text { libraries_archives_for_ } \\
\text { all_assessment.txt }\end{array}$ \\
\hline $\mathbf{2}$ & $\begin{array}{l}\text { [electronic access], encouraging library } \\
\text { use, user satisfaction, and choice of books } \\
\text { and materials, library authorities shou[ld } \\
\text { take into account the needs of socially } \\
\text { excluded people]. }\end{array}$ & $\begin{array}{l}2001-\text { DCMS - } \\
\text { libraries_archives_for_ } \\
\text { allaassessment.txt }\end{array}$ \\
\hline $\mathbf{3}$ & $\begin{array}{l}\text { This is not a shop but it offers people as } \\
\text { much choice as a department store, to find } \\
\text { just the course, [information, film or music } \\
\text { that they want]. }\end{array}$ & $\begin{array}{l}\text { Framework_for_the_F } \\
\text { uture1.txt }\end{array}$ \\
\hline $\mathbf{5}$ & $\begin{array}{l}\text { [pro]vision. Libraries work by giving people } \\
\text { enormous choice over how they can use } \\
\text { the shared resources for t[heir own ends]. }\end{array}$ & $\begin{array}{l}\text { Framework_for_the_F } \\
\text { uture1.txt }\end{array}$ \\
\hline $\mathbf{5}$ & $\begin{array}{l}\text { [Libraries, like parks, are shared spaces in } \\
\text { which people can choose from any number } \\
\text { of acti]vities. It is that combination of } \\
\text { community and choice, public provision for } \\
\text { private pleasure, which ma[kes libraries so } \\
\text { special]. }\end{array}$ & $\begin{array}{l}\text { Framework_for_the_F } \\
\text { uture1.txt }\end{array}$ \\
\hline
\end{tabular}




\begin{tabular}{|c|c|c|}
\hline 6 & $\begin{array}{l}\text { [Services have worked with excluded black } \\
\text { youngsters in Edge Hil]l and housebound } \\
\text { readers to provide them with more choice. } \\
\text { It is one of thirty-three authorities involved } \\
\text { i[n the Branching Out project]... }\end{array}$ & $\begin{array}{l}2003-\text { DCMS }- \\
\text { Framework_for_the_F } \\
\text { uture2.txt }\end{array}$ \\
\hline 7 & $\begin{array}{l}\text { [make comments]or complaints about } \\
\text { services and it gives them a choice of the } \\
\text { way in which they can receive a reply. }\end{array}$ & $\begin{array}{l}2003-\text { DCMS }- \\
\text { Framework_for_the_F } \\
\text { uture2.txt }\end{array}$ \\
\hline 8 & $\begin{array}{l}\text { [developed a ] fiction and poetry stock tool } \\
\text { to encourage a wide choice of quality } \\
\text { library provision in these areas. }\end{array}$ & $\begin{array}{l}2005-r \text { DCMS } \\
\text { public_libraries_Select } \\
\text { Committee_Respons } \\
\text { e.txt }\end{array}$ \\
\hline 9 & $\begin{array}{l}\text { charg[es must be tended effectively by } \\
\text { access to a wide choice of suitable } \\
\text { material, as well as attractive envi[rons, at } \\
\text { local libraries]. }\end{array}$ & $\begin{array}{l}2005 \text { - DCMS - } \\
\text { public_libraries_Select } \\
\text { Committee_Respons } \\
\text { e.txt }\end{array}$ \\
\hline 10 & $\begin{array}{l}\text { Libraries are excellent at engaging with } \\
\text { young people, wor[rking collaboratively to } \\
\text { give them the 'voice and choice' heralded } \\
\text { in by the government's youth strategy }\end{array}$ & $\begin{array}{l}2008 \\
\text { intro_to_MLA.txt }\end{array}$ \\
\hline 11 & $\begin{array}{l}\text { [make informed choices] and decisions. } \\
\text { Because people use them through choice } \\
\text { and on their own terms, they can help } \\
\text { users feel [ empowered and in control]. }\end{array}$ & $\begin{array}{l}2008 \\
\text { intro_to_MLA.txt }\end{array}$ \\
\hline 12 & $\begin{array}{l}\text { [identify areas for savings which do not } \\
\text { impact on fron]t line services. (d) threaten } \\
\text { residents with the choice of library closures } \\
\text { or neglecting services to th[e elderly]... }\end{array}$ & $\begin{array}{l}2009-\quad \text { DCMS - } \\
\text { LibrariesReview_cons } \\
\text { ultation.txt }\end{array}$ \\
\hline 13 & $\begin{array}{l}\text { [It will be delivered within] one week free of } \\
\text { charge to the branch of your choice, or in } \\
\text { the post to you for the price of postage [ } \\
\text { (like mail order DVD rentals)]. }\end{array}$ & $\begin{array}{l}2009-\quad \text { DCMS - } \\
\text { LibrariesReview_cons } \\
\text { ultation.txt }\end{array}$ \\
\hline 14 & $\begin{array}{l}\text { [whose responsibility it]is? If it is to be } \\
\text { public libraries - the logical choice, then } \\
\text { they show little signs of helping e-citizen [to } \\
\text { survive in a digital world]. }\end{array}$ & $\begin{array}{l}2009-\quad \text { DCMS } \\
\text { LibrariesReview_cons } \\
\text { ultation.txt }\end{array}$ \\
\hline 15 & $\begin{array}{l}\text { [welcome to stay as long as y]ou like. } \\
\text { Libraries need to be a "third place" of } \\
\text { choice rather than a last resort for } \\
\text { increasingly isola[ted or marginalised } \\
\text { groups]. }\end{array}$ & $\begin{array}{l}2009-\quad \text { DCMS } \\
\text { LibrariesReview_cons } \\
\text { ultation.txt }\end{array}$ \\
\hline 16 & $\begin{array}{l}\text { [Successful Library services must] }{ }^{2} \text { be } \\
\text { able to position themselves as partners of } \\
\text { choice and offer services of recognised } \\
\text { value to local [ policy goals]. }\end{array}$ & $\begin{array}{l}2010-\text { DCMS - } \\
\text { Modernisation Review } \\
\text { - Report.txt }\end{array}$ \\
\hline
\end{tabular}

Note: Table adapted from (Weber, 1990). 
As can be seen from the KWIC List and concordances (Table 1), choice first appears in the publications in 2001 in relation to providing the users with a "choice in books"(DCMS, 2001b). Framework is quite prescriptive about how it wishes public libraries to fit into its plans regarding government policy goals regarding socially inclusive services and sets down what it feels should inform the modern mission of libraries: evolution, public value, distinctiveness, and local interpretations of national programmes. Libraries should build on traditional services and their "distinctiveness" by building on their "open, neutral and self-help culture" (DCMS: 2003) and not replicate the services offered by other providers. The text is very aspirational in nature, but for some (Goulding, 2006) the only distinguishing feature is that it reinstates the importance of books and reading . In 2010,the role of the public library is clearly linked with wider local policy goals rather than just to meet the needs of the service per se: "Successful Library services must be able to position themselves as partners of choice and offer services of recognised value to local policy goals" (DCMS, 2010).

\section{Narratives of Coproduction}

There is also evidence of non-consumerist narratives in the public service discourses including an emphasis on community and responsibility which Needham collates under the heading of coproduction. New Labour's discourse moved away from the passive citizen to representing the citizen as an active self-sustaining individual who volunteers and is involved in mutual self-help which ultimately contributes to society by reducing costs and participating in community regeneration. It is a mixture of social democratic conceptions of the citizen and one dominated by the neoliberal concern to "liberate" the citizen from the state. An AntConc search for the term "active" highlighted the following coproduction narrative:

Active citizenship is about people taking the opportunity to get involved 'in defining and tackling problems of their communities and improving their quality of life'... Taking part in community engagement and volunteering offers active citizens the opportunity to learn and develop their skills whilst benefiting the wider community (MLA, 2006).

In neoliberal discourses, the citizen's role and rights in society are coupled with social responsibilities (Clarke, 2005). The latter involves taking responsibility for their own health and well-being by being responsible citizens (p.451). Notably, the move from the welfarist, collective citizen is characterised by the neoliberal "communal citizen" (p.452), whereby responsibility appears as a façade behind which the state can transfer its responsibilities to the individual:

Libraries have a huge opportunity to play an even more central role in future. We live in a society in which knowledge, skills and information are becoming more important to our lives, economically, socially and as citizens... The ability to make sense of and use the welter of information available to us from the media and the internet is vital to our ability to make choices and exercise our democratic rights as citizens (DCMS, 2003).

Lastly, evidence of narratives providing users with a more productive role in shaping service delivery was examined under the term "opportunity". The earlier publications 
(DCMS, 1998) talked about opportunity "to inform and contribute" and in terms of "telecommunication technologies, which opens up the opportunity for libraries to provide co-operative services" (DCMS, 1999a). In Framework the terminology is more visionary and more abstract in nature, such as libraries having "the opportunity to achieve their full potential" and, "Libraries have a huge opportunity to play an even more central role in future" (DCMS, 2003). It is not until 2010, that there is direct evidence of "opportunity" being used in terms of giving the user a more productive and active role in shaping the service, "an opportunity to access information and to participate as a citizen", and "An opportunity to have your say and get involved in shaping the service (DCMS, 2010).

The evolution of the word "community" for New Labour and successive governments places more emphasis on the individual's responsibility to the community (Fairclough, 2010) rather than the responsibility of business (p.38). Moreover, community has become known in moral terms where the rights of individuals carry responsibilities and duties. AntConc was used to search for the terms "duties", "responsibilities" and "rights" and Table 2 provide some indication of the top ten most frequently occurring uses of the terms in the public library documents (See Appendix C for the full set of results).

Table 2. Ordered Word Frequency Lists, Cluster Tokens: Duties, Rights, and Responsibilities 1998 -2010

\begin{tabular}{|l|l|l|l|l|l|l|}
\hline Rank & $\begin{array}{l}\text { Frequency } \\
\text { N=100 }\end{array}$ & $\begin{array}{l}\text { Cluster } \\
\text { Token: } \\
\text { Duties }\end{array}$ & $\begin{array}{l}\text { Frequency } \\
\text { N=102 }\end{array}$ & $\begin{array}{l}\text { Cluster } \\
\text { Token: } \\
\text { Rights }\end{array}$ & $\begin{array}{l}\text { Frequency } \\
\text { N=108 }\end{array}$ & $\begin{array}{l}\text { Cluster Token: } \\
\text { Responsibilities }\end{array}$ \\
\hline $\mathbf{1}$ & 26 & $\begin{array}{l}\text { statutory } \\
\text { duties }\end{array}$ & 13 & $\begin{array}{l}\text { Human } \\
\text { Rights }\end{array}$ & 14 & $\begin{array}{l}\text { and } \\
\text { responsibilities }\end{array}$ \\
\hline $\mathbf{2}$ & 11 & $\begin{array}{l}\text { duties } \\
\text { under }\end{array}$ & 8 & rights and & 11 & $\begin{array}{l}\text { responsibilities } \\
\text { for }\end{array}$ \\
\hline $\mathbf{3}$ & 9 & duties and & 6 & Rights Act & 10 & $\begin{array}{l}\text { responsibilities } \\
\text { of }\end{array}$ \\
\hline $\mathbf{4}$ & 5 & their duties & 5 & the rights & 3 & $\begin{array}{l}\text { its } \\
\text { responsibilities }\end{array}$ \\
\hline $\mathbf{5}$ & 3 & duties, the & 4 & of rights & 3 & $\begin{array}{l}\text { of } \\
\text { responsibilities }\end{array}$ \\
\hline $\mathbf{6}$ & 3 & its duties & 4 & rights of & 3 & $\begin{array}{l}\text { the } \\
\text { responsibilities }\end{array}$ \\
\hline $\mathbf{7}$ & 3 & of duties & 4 & rights to & 3 & $\begin{array}{l}\text { their } \\
\text { responsibilities }\end{array}$ \\
\hline $\mathbf{8}$ & 2 & $\begin{array}{l}\text { conflicting } \\
\text { duties }\end{array}$ & 3 & $\begin{array}{l}\text { human } \\
\text { rights }\end{array}$ & 14 & $\begin{array}{l}\text { and } \\
\text { responsibilities }\end{array}$ \\
\hline $\mathbf{9}$ & 2 & duties of & 3 & rights as & 11 & $\begin{array}{l}\text { responsibilities } \\
\text { for }\end{array}$ \\
\hline $\mathbf{1 0}$ & 2 & $\begin{array}{l}\text { duties } \\
\text { outlined }\end{array}$ & 3 & $\begin{array}{l}\text { rights, } \\
\text { benefits }\end{array}$ & 10 & $\begin{array}{l}\text { responsibilities } \\
\text { of }\end{array}$ \\
\hline
\end{tabular}

Note: Table adapted from Weber (1990). 
As can be deduced from Table 2, the term "duties" is mentioned 100 times in the documents and of those 26 relates to the government's statutory duties to the public library service. On closer examination, this relates to breach of its statutory duties and secure discharge of the statutory duties. Therefore, the role of the government is more paternalistic to ensure the public library service does not "default on its statutory rights". The word "rights" appears 102 times in the 51 Public library documents over 1998-2010. Most of these are in the collocation "human rights" (13) and 9 times in collocations with access, democratic, fundamental, cultural, and borrowing, rights management, welfare and digital rights. Four results are "rights and" followed by responsibilities, equalities, freedom of others and benefits.

Next, there are 108 occurrences of "responsibilities" in the documents, collocated with terms such as dual, executive, funding, and framework and statutory. Responsibilities is also collocated with dual and linked with "responding to the needs of society today" (DCMS, 2001b). More specifically, "responsibilities for" was examined and revealed various connections with staff, members, individuals and various organisations. On closer examination, "identifying the responsibilities of individuals" (MLA, 2006) related to setting up community partnerships and establishing the "Responsibilities that the community want to take on" (p.14). These findings reflect New Labour discourse on the community (Fairclough, 2000) which is based on the notion that the individual is a product of their relationships to others in families and communities (p.38).

\section{Dissolving the Public Realm: Professional Language}

\section{Neoliberal Strategies of Institutionalisation}

There has been an increased focus on making public services more "business-like" (Barnett, 2002) and responsive to service users (p.310). Moreover, Budd (2008, p.175) argues that the acceptance of neoliberal ideology is done insidiously, and by introducing an idea to an individual in such a way that it appeals to their common sense or logic, their emotions or even states the opposite of what it is in reality. This is what Foucault refers to as the "will to truth" and can effectively institutionalise discourses to a point that a discourse can display dual allegiances. As such, the language of neoliberalism is used even whilst espousing arguments for services, collections and access aimed at communities (Budd, 2008, p.175). In the People's Network, for instance, the Government asserts that the public library is more than able to rise to these challenges of the modern society:

Our public library system is one of our most important and respected public services, offering levels of customer usage, satisfaction and brand loyalty that most private sector organisations can only dream about (DCMS, 1998, p.1).

It is revealing that the government publication uses the language of marketing to describe the modern library service as a brand. This is all the more concerning for a library profession that is accused by some as lacking proactiveness in trying to bring about change in the profession and of reacting to rather than leading government policy (Usherwood, 1999). 
Budd (1997, p.319) warns that librarians have to be careful about the language they choose to adopt and practice, which he feels should "flow from as clear an idea of purpose as possible and like McMenemy (2007) that this should not be influenced by pressures of capitalism and consumption. Librarians have to be aware of what message the language they use is communicating both to fellow librarians and those outside the profession. As such, it is important to ascertain whether a customer service stance affects the service offered and whether librarians who use this language recognise that the language they use is not neutral and that it is possibly "culturally, politically, economically and intellectually charged" (Budd, 1997, p.310). Usherwood argues that:

In a true public library the user is a citizen rather than a customer. The commercial sector is not concerned with citizenship. Customers and consumers are viewed differently from citizens. (p.47)

Moreover, the core values of the public library service appear to fit well with the ongoing modernisation of public services of New Labour and successive governments. In the publication New Library: The People's Network (DCMS, 1998, p.5), the government announced that it "believes ...public libraries play a vital social, economic, and educational role in daily life of the nation and Batt (as cited in BroadyPreston and Cox, 2000, p.149) hailed the former publication as "the most important document ever to be prepared on the UK public library service", and was one indication of the Government's commitment to the public library service:

Libraries contribute to four of this Government's most important policy objectives. They underpin education, providing essential support for school children, students, and lifelong learners; they enhance public access to the world's storehouse of knowledge and information; they promote social inclusion, by helping to bridge the gap between those who can afford access to information and those who can't; and, increasingly, they have a role to play in the modernisation and delivery of public services. (DCMS, 1998, p.1)

Likewise, in Framework for the Future there is an implicit suggestion that in order to survive, libraries have to reform and adapt to their surrounding environments and that their future success" is dependent on their ability to meet user expectations:

Libraries thrive best with a sense of mission. The future success of libraries depends on their continually renewing and communicating that sense of mission for a very different society. This is a society in which people have access to a much wider range of sources for pleasure, entertainment, information and learning but in which there are social inequalities, particularly of access to and of capability in reading, learning and using digital services. (DCMS, 2003)

\section{Conclusions}

This chapter contributes to wider discussions and trends within public librarianship surrounding methods and methodologies. Notably, it illustrates the value of combining quantitative and qualitative methods to look at general and more politically 
sensitive issues surrounding the impact of neoliberal discourse on public librarianship.

Moreover, it adds to the growing trend towards the triangulation of methods by combining content and discourse analysis to perform LIS research. This also reflects the linguistic turn in the social sciences and humanities which emphasises the role of language in the construction of social reality (Phillips \& Hardy, 2002; Talja, 1999). The pluralist approach adopted in the chapter provides interesting data on a subject that was until recently neglected in public library research. It connects the overarching theory of neoliberalism with the narratives of managerialism and consumerism which have pervaded the private and public sector over the last thirty years. In particular, the shift towards a more managerialist and consumerist society and the impact it has had on public librarianship and the public library as a functioning democratic public sphere is tentatively explored.

In particular, the chapter adds to the literature that acknowledges how language is not neutral and how it is used by neoliberalists to introduce reform and more radical public service restructuring. The discussion reveals how narratives of elitism and decline are used to describe the public library service, which reinforces negative stereotypes of a service in distress. The growing "anti-professional" culture pervading public service along with calls for "value for money" reflects a managerialist shift in public service provision, which emphasises neoliberal political values at the expense of professional values.

Next, the chapter concentrates on how the call for public libraries to learn from the success and best practice of bookstores is part of a wider neoliberal discourse in UK politics that turns to the private sector for guidance on how to manage public sector service provision (McMenemy, 2009c). The fact that libraries and bookstores work from an opposing ethos; the former to provide free access to information for all and the latter to make a profit from selling its goods, is never mentioned in the political rhetoric. Those who do not agree with the political discourse surrounding public libraries being more commercial in nature are deemed illogical and to somehow have missed the point.

The chapter also connects with wider narratives of consumerism surrounding the rise of the citizen consumer and how these discourses have put further pressure on public library services to become more commercial in nature. There has been a move away from a welfarist approach to a consumerist approach which emphasises individual consumer choice, where choice has been used as a rhetorical tool to introduce public sector reforms. Furthermore, the identification of non-consumerist narratives adds to earlier research by Needham (2007) by revealing that the neoliberal concern with "liberating" the citizen from the state has at its root the desire for the state to transfer risk and costs associated with public service provision to the community.

Finally, the chapter contributes to a better understanding of how far neoliberal theories have impacted on public librarianship through the transformation of professional language by analysing fifty-one public library documents using content and discourse analysis. It is shown that language is a powerful persuasive tool that can be used rhetorically to introduce policies that on the surface may appear to 
benefit the service. The naturalisation of the language of the market such as calling patrons "customers" has become so entrenched in the mindset that it is now part of everyday language. The monetary and transactional connotations associated with a term like "customer" to describe a public sector user would have appeared inappropriate to many thirty years ago, but due to the steady naturalisation of neoliberal discourse such terms appear innocuous. Consequently, individuals are "blindly" using neoliberal terminology without realising it or indeed seeing it as a problem (Budd, 1997). As such, the adoption of the private sector language to appease political leaders may be potentially undermining the notion that that public libraries exist to offer a public service to citizens, not customers.

\section{References}

Aharony, N. (2009). Librarians' attitudes towards marketing library services. Journal of Librarianship and Information Science, 41(1), 39-50.

Audunson, R. (2005). How do Politicians and Central Decision- Makers View Public libraries? The case of Norway. . IFLA Journal, 31(2), 174-182.

Barnett, N. (2002). Including ourselves: New Labour and engagement with public service. . Management Decision, 40(4), 310-317.

Basu, R. (2004). The rationalization of neoliberalism in Ontario's public education system, 1995-2000. Geoforum, 35, 621-634.

Broady-Preston, J., \& Cox, A. (2000). The public library as street corner university: back to the future? . New Library World, 101(1156), 149-160.

Budd, J. M. (1997). A Critique of Customer and Commodity. College \& Research Libraries, 58(4), 309-320.

Budd, J. M. (2008). Self-Examination: The Present and Future of Librarianship. Westport: Libraries Unlimited.

Budd, J. M., \& Raber, D. (1996). Discourse Analysis: Method and Application in the Study of Information. Information Processing and Management, 32(2), 217226.

Buschman, J. E. (2003). Dismantling the Public Sphere: Situating and Sustaining Librarianship in the Age of the New Public Philosophy. Westport: Libraries Unlimited.

Buschman, J. E. (2005). On Library and the Public Sphere. Library Philosophy and Practice, 7(2), 1-8.

Chun, C. W. (2009). Contesting neoliberal discourses in EAP: Critical praxis in an IEP classroom. . Journal of English for Academic Purposes 8(2), 111-120.

Clarke, J. (2004). Dissolving the public realm?: The logics and limits of neoliberalism. . Journal of Social Policy 33(1), 27-48.

Clarke, J. (2005). New Labour's citizens: activated, empowered, responsibilized, abandoned? Critical Social Policy, 25(4), 447-463.

Clarke, J. (2007a). Citizen- consumers and public service reform: At the limits of neo-liberalism? . Policy Futures in Education 5(2), 239-248.

Clarke, J. (2007b). Unsettled Connections: Citizens, consumers and the reform of public services. Journal of Consumer Culture, 7(2), 159-178.

Clarke, J., \& Newman, J. (1997). The managerial state : power, politics and ideology in the remaking of social welfare. London: Sage.

Clarke, J., \& Newman, J. (2007). What's in a Name? New Labour's citizenconsumers and the remaking of public services. Cultural Studies, 21(4-5), 738-757. 
Clarke, J., Newman, J., Smith, N., Vidler, E., \& Westmarland, L. (2007). Creating Citizen-Consumers: Changing Publics and Changing Public Services. . London: Sage.

Coates, T. (2004). Who's in Charge? Responsibility for the public library service. London: Libri Trust.

DCMS. (1998). New Library: The People's Network" The Government's Response London: Department for Culture, Media and Sport.

DCMS. (1999a). Libraries and the Regions: A Discussion Paper London: Department for Culture, Media and Sport.

DCMS. (1999b). Libraries for all: social inclusion in public libraries: policy guidance for Local Authorities in England. London: Department for Culture, Media and Sport.

DCMS. (2001a). Appraisal of Annual Library Plans 2000 - Report on Outcomes and Issues. . London: Department for Culture, Media and Sport.

DCMS. (2001b). Libraries, Museums, Galleries and Archives for All: Co-operating Across the Sectors to Tackle Social Exclusion. London: Department for Culture, Media and Sport.

DCMS. (2003). Framework for the Future: Libraries, Learning and Information in the next decade. London: Department for Culture, Media and Sport.

DCMS. (2005). Government Response to the Third Report of the Culture, Media and Sport Select Committee, Session 2004- 2005: Public Libraries. London: Department for Culture, Media and Sport.

DCMS. (2009a). Empower, Enrich, Inform: The modernisation review into public librares: a consultation document. London: Department for Culture, Media and Sport.

DCMS. (2009b). Third Sector Strategy. London: Department for Culture, Media and Sport.

DCMS. (2010). The Modernisation Review of Public Libraries - a Policy Statement. London: Department for Culture, Media and Sport.

Fairclough, N. (2000). New Labour, New Language? . London: Routledge.

Fairclough, N. (2010). Critical Discourse Analysis: The Critical Study of Language (2nd ed.). Harlow: Pearson Educational Publishing.

Goulding, A. (2006). Public Libraries in the 21st Century: Defining Service and Debating the Future. . Aldershot: Ashgate.

Harvey, D. (2005). A Brief History of Neoliberalism. Oxford: Oxford University Press.

Hood, D., \& Henderson, K. (2005). Branding in the United Kingdom public library service. New Library World, 106(1208/1209), 16-28.

Johannsen, C. G. (2004a). Managing fee-based public library services: values and practices. Library Management, 25(6/7), 307-315.

Johannsen, C. G. (2004b). "Money makes the world go round" - fee-based services in Danish public libraries 2000-2003. New Library World, 105(1196/1197), 21 32.

Kann-Christensen, N., \& Andersen, J. (2009). Developing the library: Between efficiency, accountability and forms of recognition. Journal of Documentation, 65(2), 208-222.

Kann-Christensen, N., \& Pors, N. O. (2004). The legitimacy of public libraries: crosspressures and change processes. New Library World, 105(1204/1205), 330336.

Kotler, P., \& Levy, S. J. (1969). Broadening the Concept of Marketing. The Journal of Marketing 33(1), 10-15. 
McMenemy, D. (2007). Managerialism: a threat to professional librarianship? . Library Review, 56(6), 445-449.

McMenemy, D. (2008). A broken relationship: pushing direct marketing to the public library user. Library Review, 57(6), 413-415.

McMenemy, D. (2009a). The Public Library. London: Facet Publishing.

McMenemy, D. (2009b). Rise and demise of neo-liberalism: time to reassess the impact on public libraries. Library Review, 58(6), $400-404$.

McMenemy, D. (2009c). Telling a true story or making it up: Discourse on the effectiveness of the bookshop model for public libraries. Library Review, 58(1), 5-9.

MLA. (2006). Community engagement in public libraries: A report on current practice and future developments. . London: Department for Culture, Media and Sport.

Needham, C. (2007). The Reform of Public Services Under New Labour: Narratives of Consumerism. . Aldershot: Palgrave MacMillan.

Panda, K. C., \& Mandal, M. (2006). Corporate culture in libraries and information centers to promote "knowledge-based business" in IT era. . Library Management, 27(6/7), 446-459.

Parker, S., Ray, K., \& Harrop, K. (2001). The bidding culture in the UK public library - a case study approach. Library Management, 22(8/9), 404-410.

Phillips, N., \& Hardy, C. (2002). Discourse Analysis: Investigating Processes of Social Construction. Thousand Oaks, CA: Sage.

Rooney-Browne, C. (2008). Changing the way we look at libraries?: An evaluation of East Renfrewshire's Look at Libraries festival. Library Review, 57(1), 50-66.

Rooney-Browne, C., \& McMenemy, D. (2010). Public libraries as impartial spaces in a consumer society: possible, plausible, desirable? New Library World, 111(11/12), 455-467.

Rydin, Y. (2005). Geographical knowledge and policy: the positive contribution of discourse studies. Area, 37(1), 73-78.

Salecl, R. (2011). The Tyranny of Choice: Profile Books.

Schwartz, B. (2005). The Paradox of Choice: Why More is Less. New York: Harper Collins.

Talja, S. (1999). Analyzing Qualitative Interview Data: The Discourse Analytic Method. 21, 4(459-477).

Usherwood, B. (1996). Re-evaluating public library management. London: Library Association.

Usherwood, B. (1999, 20 - 28 August 1999). Value and impact studies. Paper presented at the International Federation of Library Associations and Institutions) 65th IFLA Council and General Conference., Bangkok, Thailand.

Usherwood, B. (2007). Equity and excellence in the public library : why ignorance is not our heritage. Aldershot: Ashgate.

Weber, R. P. (1990). Basic Content Analysis Newbury Park, CA: Sage. 


\section{Appendix - Reference Corpus: Public Library Documents Used in Data Analysis (in date of publication order)}

DCMS.(1998) "New Library: The People's Network" The Government's Response

[Online] Department for Culture, Media and Sport. Available at:

http://www.culture.gov.uk/images/publications [Accessed 8 November 2010].

DCMS.(1999a) Libraries and the Regions: A Discussion Paper [Online] Department

for Culture, Media and Sport. Available at:

http://www.culture.gov.uk/images/publications [Accessed 8 November 2010].

DCMS., (1999b). The Establishment of a Museums, Libraries and Archives Council:

Report of the Design Group. [Online] Department for Culture, Media and Sport.

Available at: http://www.culture.gov.uk/images/publications [Accessed 8 November

2010].

DCMS., (1999). Libraries for all: Social Inclusion in Public Libraries. [Online]

Department for Culture, Media and Sport. Available at:

http://www.culture.gov.uk/images/publications [Accessed 8 November 2010].

DCMS., (2001a). Appraisal of Annual Library Plans 2000 - Report on Outcomes and Issues. [Online] Department for Culture, Media and Sport. Available at:

http://www.culture.gov.uk/images/publications [Accessed 8 November 2010]. DCMS., (2001b). Comprehensive, Efficient and Modern Public Libraries - Standards and Assessment. [Online] Department for Culture, Media and Sport. Available at: http://www.culture.gov.uk/images/publications/ [Accessed 8 November 2010]. DCMS., (2001c). Analysis of the Consultation on Draft Public Library Standards. [Online] Department for Culture, Media and Sport. Available at:

http://www.culture.gov.uk/images/publications [Accessed 8 November 2010]. DCMS, (2001d). Libraries, Museums, Galleries and Archives for All: Co-operating Across the Sectors to Tackle Social Exclusion. [Online] Department for Culture, Media and Sport. Available at: http://www.culture.gov.uk/images/publications [Accessed 8 November 2010].

DCMS., (2002a). Appraisal of Annual Library Plans and approach to the Public Library Standards - (2001) Report on outcomes and issues. [Online] Department for Culture, Media and Sport. Available at: http://www.culture.gov.uk/images/publications [Accessed 8 November 2010].

DCMS., (2002b). Appraisal of Annual Library Plans (2002). [Online] Department for Culture, Media and Sport. Available at: http://www.culture.gov.uk/images/publications [Accessed 8 November 2010].

Leadbeater, C., (2003). Overdue: how to create modern public library service.

[Online] Demos Available at: http://www.demos.co.uk/files/overdue.pdf [Accessed 8

November 2010].

DCMS., (2003). Framework for the Future: Libraries, Learning and Information in the next decade. [Online] Department for Culture, Media and Sport. Available at:

[Accessed 8 November 2010].

DCMS., (2004a). Report to Parliament on Public Library Matters. [Online]

Department for Culture, Media and Sport. Available at:

http://www.culture.gov.uk/images/publications [Accessed 8 November 2010].

DCMS., (2004b). Public Library Position Statements (2003). [Online] Department for Culture, Media and Sport. Available at: http://www.culture.gov.uk/images/publications [Accessed 8 November 2010].

Coates. T., (2004). Who's in Charge? Responsibility for the public library service [Online] London: Libri. 
MLA., (2004a). New Directions in Social Policy: Cultural Diversity for museums, libraries and archives. [Online] Department for Culture, Media and Sport. Available at: http://www.culture.gov.uk/images/publications [Accessed 8 November 2010]. MLA., (2004b). New Directions in Social Policy: Health Policy for museums, libraries and archives. [Online] Department for Culture, Media and Sport. Available at: http://www.culture.gov.uk/images/publications [Accessed 8 November 2010]. MLA., (2004c). New Directions in Social Policy: developing the evidence base for museums, libraries and archives in England. [Online] Department for Culture, Media and Sport. Available at: http://www.culture.gov.uk/images/publications [Accessed 8 November 2010].

MLA., (2005). Public Libraries and Community Cohesion Developing indicators. [Online] Department for Culture, Media and Sport. Available at:

http://www.culture.gov.uk/images/publications [Accessed 8 November 2010]. DCMS., (2005). Government Response to the Third Report of the Culture, Media and Sport Select Committee, Session (2004)- (2005): Public Libraries. [Online] Department for Culture, Media and Sport. Available at:

http://www.culture.gov.uk/images/publications/public libraries Select Committee $\mathrm{Re}$ sponse.pdf [Accessed 29 October (2009)].

DCMS., (2006a). Public Library Service Standards. [Online] Department for Culture, Media and Sport. Available at: http://www.culture.gov.uk/images/publications [Accessed 8 November 2010].

DCMS., (2006b). A Research Study of 14-35 year olds for the Future Development of Public Libraries. [Online] Department for Culture, Media and Sport. Available at: http://www.culture.gov.uk/images/publications [Accessed 8 November 2010]. MLA., (2006a). Community engagement in public libraries: $A$ report on current practice and future developments. [Online] Department for Culture, Media and Sport. Available at: http://www.culture.gov.uk/images/publications [Accessed 8 November 2010].

MLA., (2006b). Transformational Leadership Behaviour among Participants in the 'Leading Modern Public Libraries' Programme. Analysis of Results and Recommendations for Action. [Online] Department for Culture, Media and Sport. Available at: http://www.culture.gov.uk/images/publications [Accessed 8 November 2010].

MLA., (2006c). Volunteering in Museums, Libraries and Archives. [Online] Department for Culture, Media and Sport. Available at: http://www.culture.gov.uk/images/publications [Accessed 8 November 2010]. DCMS., (2007a). Public Library Service Standards. [Online] Department for Culture, Media and Sport. Available at: http://www.culture.gov.uk/images/publications [Accessed 8 November 2010].

DCMS., (2007b). A New Libraries Performance Management Framework. [Online] Department for Culture, Media and Sport. Available at: http://www.culture.gov.uk/images/publications [Accessed 8 November 2010]. MLA., (2007a). Localism, governance and the public realm: Issues for the local cultural sector. [Online] Department for Culture, Media and Sport. Available at: http://www.culture.gov.uk/images/publications [Accessed 8 November 2010]. MLA., (2007b). A blueprint for excellence: Public Libraries (2008)-2011. "Connecting People to Knowledge and Inspiration". [Online] Department for Culture, Media and Sport. Available at: http://www.culture.gov.uk/images/publications [Accessed 8 November 2010]. 
MLA., (2007c). Securing excellence; delivering for communities. [Online] Department for Culture, Media and Sport. Available at:

http://www.culture.gov.uk/images/publications [Accessed 8 November 2010].

MLA. (2007d). Museums, Libraries and Archives Council and London Libraries

Development Agency Single membership card for London's public libraries: feasibility study. [Online] Department for Culture, Media and Sport. Available at:

http://www.culture.gov.uk/images/publications [Accessed 8 November 2010].

MLA., (2008a). Museums: An introduction to libraries archives. [Online] Department for Culture, Media and Sport. Available at:

http://www.culture.gov.uk/images/publications [Accessed 8 November 2010].

MLA., (2008b)., Community Libraries Programme Evaluation: An overview of the baseline for community engagement in libraries. [Online] Department for Culture, Media and Sport. Available at: http://www.culture.gov.uk/images/publications [Accessed 8 November 2010].

MLA. (2008c). Consultation on draft guidance on the management of controversial material in public libraries. [Online] Department for Culture, Media and Sport.

Available at: http://www.culture.gov.uk/images/publications [Accessed 8 November 2010].

MLA., (2008d). Families, Learning and Culture: Inspiring Families through Museums, Libraries and Archives. [Online] Department for Culture, Media and Sport. Available at: http://www.culture.gov.uk/images/publications

MLA., (2008e). Safeguarding Guidance for Museums, Libraries and Archives. [Online] Department for Culture, Media and Sport. Available at:

http://www.culture.gov.uk/images/publications [Accessed 8 November 2010].

MLA., (2008f). Public Libraries, Archives and New Development: A Standard Charge Approach. [Online] Department for Culture, Media and Sport. Available at:

http://www.culture.gov.uk/images/publications [Accessed 8 November 2010].

DCMS., (2009a). Capturing the Impact of Libraries: Final Report. [Online] BOP Consulting. Available at:

http://www.culture.gov.uk/reference library/publications/5914.aspx [Accessed 29

September (2009)].

DCMS., (2009b).. A Local Inquiry into the Public Library Service Provided by Wirral

Metropolitan Borough Council. [Online] Department for Culture, Media and Sport.

Available at: [Accessed 8 November 2010].

DCMS., (2009c). Empower, Enrich, Inform: The modernisation review into public librares: a consultation document. [Online] Department for Culture, Media and Sport. Available at: http://www.culture.gov.uk/images/publications [Accessed 8 November 2010].

DCMS., (2009d). Swindon Borough Council Library Service Review and Data Analysis. [Online] Department for Culture, Media and Sport. Available at: http://www.culture.gov.uk/images/publications [Accessed 8 November 2010] DCMS., (2010). Summary of Responses to the Consultation on the Modernisation Review of Public Libraries. [Online]. Available at: http://www.dcms.gov.uk [Accessed 27 November 2010]. 